\title{
AN AGENDA FOR INVESTIGATION: SHOULD THE APA BE AMENDED TO PROVIDE STANDARDS FOR AGENCY REVIEW OF ADIMINISTRATIVE TRIALS?
}

\author{
WILLIAM FAUVER*
}

The integrity of the administrative processes of the federal government can be eroded not only by recognizable actions against the public interest, but also by the neglect of means to improve the basic fairness and efficiency of government decision-making. This article suggests a need for thorough investigation of a crucial aspect of the federal administrative process-the review of an administrative law judge's decisions by a government agency.

When the Administrative Procedure Act (APA) was passed in $1946,{ }^{1}$ no provision was made for a well-structured review of the decisions of administrative law judges (then designated hearing examiners), ${ }^{2}$ and there is reason to think that this omission has weakened the integrity and professionalisin of the administrative process. To even the casual observer, problems of delay, expense and frustration in the federal administrative review process nust be evident. Among the more common problems that contribute to the ills of the administrative system, the following require no detailed documentation:

1. As federal laws begin to place greater burdens upon wealthy and powerful interests, there is an inevitable increase in the tendency to exert political influence upon administrative agencies.

2. A persistent anoinaly exists in the contrast between the exacting standards governing the selection and independence of ad-

\footnotetext{
$*$ Administrative Law Judge, U.S. Department of the Interior; Chairman, Committee on Agency Review, Federal Administrative Law Judges Conference. LL.B. 1957, University of Alabama.

The opinions expressed in this article are those of the author and do not necessarily represent those of the Department of the Interior or the Federal Administrative Law Judges Conference.

1. Administrative Procedure Act, ch. 324, 60 Stat. 237 (1946) (codified in 5 U.S.C. \$ 551 et seq. (1970)).

2. The title change to "Administrative Law Judge" was effected by Civil Service Regulation on August 19, 1972. 37 Fed. Reg. 16787 (1972).
} 
ministrative law judges under the APA and the lack of any comparable standards respecting review officials ${ }^{3}$ appointed by the agencies.

3. Agency review of an administrative law judge's decisions frequently involves a de novo appraisal of the evidence and the issues, resulting in considerable delay, cost to the taxpayer and the parties, and loss of efficiency and integrity in the administrative process.

4. Oversight of an agency's decision-making process is often frustrated by a lack of clear standards against which the agency's performance can be measured by the judiciary, the Congress and the public.

As early as the reports of the Hoover Commission and its Task Force in $1955^{4}$ and as recently as the Ash Council Report in 1971, ${ }^{5}$ researchers have recommended procedural reforms that would give greater finality to the decisions of administrative law judges, thereby reducing delays, uncertainty and waste in the agency review processes.

As concluded by the Ash Council, the agencies tendency toward "systematic . . . review of decisions by agency hearing examiners," frequently characterized by "de novo review of findings and legal issues raised in hearings," has "unduly prolonged proceedings and nurtured high case backlogs leading to ineffective uses of agency resources" and unjust burdens upon the parties. ${ }^{\circ}$ To cure such ills the Council proposed:

That administrative review procedures be streamlined by limiting the scope and the time devoted to them and that the judicial review function be transferred from existing Federal courts to a new Administrative Court. ${ }^{7}$

The critical focus of administrative reform is upon the finality of the decisions of the administrative law judges. As emphasized in the

3. As used here the term "agency review officials" refers to agency employees who have been delegated authority to decide appeals from the decisions of administrative law judges. It does not refer to Presidential appointees confirmed by the Senate or to agency staff who assist in the preparation of review decisions.

4. Hoover Commission, Legal Services and Procedure, a Report to the Congress (1955); Hoover Commission, TASK ForCe ON LeoAl Services AND Procedure, Report on Legal Services and Procedure (1955).

5. The President's Advisory Council on Executive Organization, A New Regulatory Framework, Report on Selected Independent Regulatory Agencies (1971).

6. Id. at $21-22,49$.

7. Id. at 47. 
Ash Report, if the "serious deficiencies" of agency review processes "are to be overcome, it will be necessary to place a greater share of the responsibility for individual case determinations on the hearing examiners, leaving the administrator relatively free to concentrate on more appropriate ineans of formulating broad policy." The Council therefore proposed to replace "systematic review of initial decisions" with discretionary reviews "primarily for consistency with agency policy." The following statement in the Ash Report summarized the Council's support of this major proposal:

We are persuaded that limiting internal review in this way would revitalize the agency process. Administrators could concentrate on the enunciation of broad agency policy and guidelines. With clear policy directions, hearing examiners would be better able to apply agency policy to the facts at hand in inore proceedings than is generally true now. Their initial and recommended decisions should become the final agency determination. . . . .10

The earlier Hoover Commission also found excessive delays and waste in internal agency reviews ${ }^{11}$ and similarly recommended en. larging the role of hearing examiners. Thus, the Commission proposed that there should be a

corps of independent hearing commissioners, with the status of administrative trial judges, to replace the present group of hearing exmimers and to preside in the large majority of formal adjudicatory and rule making cases. These hearing commissioners should have authority as presiding officers comparable to that of trial judges . . . .

In adjudication, as distinguished from formal rule making, required under the Constitution or by statute to be made after hearing, the rules of evidence and requirements of proof as found in civil nonjury cases in the United States district courts shall be apphied, so far as practicable, except that the admission of evidence not admissible under such rules and requirements shall not be deemed ground for reversal. Parties should be afforded an opportunity to controvert facts officially noticed by agencies prior to entry of a final decision. ${ }^{12}$

A key proposal of the Hoover Commission was an "Administrative Court of the United States" to review agency decisions in APA cases. Under the proposed scheme, the new "hearing com-
8. Id. at 50.
9. Id.
10. Id. at 51 .
11. A Report to the Congress, supra note 4 , at 63.
12. Id. at 70-72. 
missioners" would be "completely independent of the agencies whose cases they hear . . . [and would be selected by, and be] under the administrative control and direction of the Administrative Court."13

If implemented, these recommendations of the Cominission would obviously require uniform standards for internal agency review. The Hoover Commission Task Force Report prescribed, among other recommendations, such standards in proposing limits on agency review authority. Although the Task Force Report was not binding upon the Commission, it was given wide distribution and represented the coinprehensive work of eminent scholars, researchers, administrators and practitioners in the administrative law field. The Task Force recommendations included:

In adjudication and rule making required under the Constitution or by statute to be made after hearing, in which the agency has not presided at the reception of the evidence, the presiding officer should prepare and file an initial decision. ${ }^{14}$

The importance of this recommendation, the Task Force explained, was "in the interest of maximum due process and efficiency. . . . Delays in the administrative process often arise out of the practice, common to many agencies, of utilizing hearing examiners to conduct hearings but not to contribute in any important degree to the process of decision." 15 The proposal was thus intended to eliminate recommended decisions in administrative adjudicatory proceedings.

Concluding that uniform standards were indeed essential to correct the existing problems, the Task Force recommended a uniform Code of Administrative Procedure for rulemaking, adjudication and internal agency review, ${ }^{16}$ with the following cornerstone for internal agency review:

Upon review of an initial decision of a presiding officer in adjudication or rule making required under the Constitution or by statute to be made after hearing, except for questions of policy delegated to the agency by the Congress, the agency should have only the powers of review that a court has upon judicial review of agency decisions. ${ }^{17}$

In 1956 the American Bar Association (ABA) endorsed the

13. Id. at 87-93 (Recommendations Nos. 5 \& 52 ).

14. TASK Force Report on Legal Services and Procedure, supra note 4, at 201.

15. Id. at 207.

16. Id. at 359-442.

17. Id. at 203. 
basic proposals of both the Hoover Commission and the Task Force to strengthen the administrative hearings process, to give greater finality to the decisions of administrative judges, and to enact a uniform Code of Administrative Procedure. As an immediate measure, the $\mathrm{ABA}$ proposed the following standard for internal agency review:

Providing that in formal adjudication the hearing officer's findings of evidentiary fact, as distinguished from ultimate conclusions of fact, shall not be set aside by the agency on review of the hearing officer's initial decision uuless such findings of evidentiary fact are contrary to the weight of the evidence. ${ }^{18}$

The Hoover Task Force and ABA studies led to an ABA bill, introduced by Senator Ervin in 1959, for a uniform Code of Federal Administrative Procedure, which included the 1956 ABA review standard. ${ }^{19}$

The Code having failed to pass, in 1961 the Subcommittee on Administrative Practice and Procedure of the Senate Judiciary Committee proposed a renewed attack on the ills of the federal administrative process, based upon its thorough knowledge of these problems as well as its appraisal of the Landis Report, which was published in December $1960.0^{20}$ As the Subcommittee reported, inter alia:

Delays, bad management, overtones of improper influence, and lack of personnel have contributed to expense, huge backlogs, and lessened effectiveness in nearly all of the departments and agencies which are charged with responsibility for carrying out the 106 regulatory laws which Congress has enacted in the public interest. . . . In every department and agency, delays in decision have resulted in increasing backlogs, and, in turn, mounting injury to all concerned.21

Of particular relevance here is the Subcommittee's recommendation which called for the enactment of legislation to increase the authority of hearing examiners. In language equally pertiment today, the Subcommittee reported:

Evidence gathered by this subcommittee, as well as by others who have inade serious studies of the workings of the administrative

18. 81 ABA REP. 375, 497 (1956).

19. S. 1070, 86th Cong., 1st Sess. (1959).

20. S. Rep. No. 1484, Subcomm. on Administrative Practice and Procedure of the SeNate Comm. ON THE Judiclary, 86th Cong., 2d Sess. (1960).

21. S. Rep. No. 168, Subcomm. on Adminstrative Practice and Procedure of the SeNate Comm. on THe Judiciary, 87th Cong., 1st Sess. 1 (1961). 
process, has established that the greatest obstacle to the effective functioning of the quasi-judicial aspects of government has been delay and expense.

... The subcommittee beheves that the readiest instrument available for a concerted effort to eliminate backlogs and delays in the administrative process is the utilization of the existing hearing examiner corps by increased delegation of authority, increased finality of their decisions, and increased authority to control the course of hearings.

The Administrative Procedure Act authorizes the various agencies to utilize inore fully the hearing examiner in reaching decisions which, in all but the rarest instances, will be the final decision of the agency. To the extent that other statutes interfere with such delegations of authority, the subcommittee recominends legislation which will not only permit, but require, the full utilization of the potential of the hearing examiner corps. ${ }^{22}$

These views, and further extensive study of the problems, resulted in the Subcommittee's proposals of major amendments to the APA in 1965. The bill, introduced by the late Senator Dirksen, provided a "clearly erroneous" standard for agency review of "findings or conclusions of material fact" and standards for the selection and independence of members of agency appeals boards; adopted certiorari review by agencies; and allowed for agency review sua sponte "only upon the ground that the decision or action [below] may be contrary to the law or agency policy, that the agency wishes to reconsider its policy, or that a novel question of policy has been presented."23 If an agency decided to review on its own motion, the bill required that the agency enter an order for review specifying the "agency policy or novel question involved." 24 This approach, it may be noted, has unuch in common with the Ash Council's subsequent recommendations to limit internal agency review.

Despite the repeated recommendations of these leading authorities to reduce the scope of agency review and to give greater finality to decisions of APA judges, in only two agencies, the Civil Aeronautics Board and the Occupational Safety and Health Review Commission, has any notable action been taken in this direction. The APA's provisions on adjudicatory processes have not been amended, ${ }^{25}$

22. Id. at 7-8.

23. S. 1336, 89th Cong., 1st Sess. $\$ 8$ (c) (1965) (introduced in the Senate on March 4, 1965 and passed by the Senate on June 21, 1966).

24. $I d$. 
agencies continue the droning, virtually systematic review of decisions of administrative law judges, and the costs and delays of administrative litigation continue to mount.

Unlike the procedures in all other agencies, internal review at the $\mathrm{CAB}$ and OSHRC is both discretionary (by certiorari or by the agency's own motion) and limited as to the grounds on which review may be sought. ${ }^{26}$ The improvements resulting from the $\mathrm{CAB}$ changes (adopted in 1962) are well-known and well-documented, ${ }^{27}$ but even these reforms (and the OSHRC procedures) fall far short of the proposals discussed earlier in that they do not accord consistent weight to the findings of the administrative law judges. ${ }^{28}$

The agencies' resistance to change is virtually unanimous. Thus, the Administrative Conference of the United States (ACUS), reflecting a consensus of the agencies, has steadfastly opposed mandatory standards for internal agency review of the decisions of administrative law judges. Its consistent position has been that "the agencies should be relied upon to employ [review standards] only when they would be useful and appropriate" as determined by each agency. ${ }^{29}$ Although the ACUS does not dispute that "[r]ecognition of a 'right' to de novo consideration by the agency members would put a halt to all efforts, which began with the APA, to accord greater administrative finality of the initial decisions of hearing examiners," it qualifies this concession as being relevant only to "appropriate cases," again, to be determined by the agency. ${ }^{30}$

25. For an exellent summary of the unsuccessful struggle for reforms in Congress since the Hoover Commission (1955) and ABA (1956) recommendations, see Kennedy, Forward: ABA Proposals for Amendments to Administrative Procedure $A c t, 24$ AD. L. REv. 371, 375-81 (1972).

26. 14 C.F.R. $\$ \$ 302.27-.28$ (1972); 29 C.F.R. $\$ 2200.42$ (1972).

27. See, e.g., Ellis, Report in Support of Discretionary Review of Decisions of Presiding Officers; Subparagraph 1(b) of Recommendation No. 6, 1 AbMIN. Conf. U.S. REP. 155, 159-68 (1970).

28. Thus, the discretionary review provisions of CAB's regulations do not prohibit de novo review of the judges' findings, whether review is on the agency's own motion or a party's petition for review. 14 C.F.R. $\$ 302.28(a)(1)-(2)(1972)$. The review procedures at OSHRC, adopted in 1971, are patterned after the CAB rules. 29 C.F.R. $\$ 2200.42$ (1972).

29. Recommendation No. 9, Administrative Conference of United States, reprinted in S. Doc. No. 24, Subcomm. on Administrative Practice and Procedure of the Senate Judiciary CoMm., 88th Cong., 1st Sess. 157 (1963). The same philosophy against uniform review standards appears in the latest ACUS reconmendation on this subject. See Recommendation No. 6, 1 ADMIN. CONF. U.S. REP. 20-22, 122-68 (1970).

30. S. Doc. No. 24 , supra note 29 , at 161 . Having suffered repeated setbacks in its struggle for mandatory review standards, the ABA has recently retreated to the view that standards, if any, should be left to the discretion of each agency. 
In addition to the limited improvements at $\mathrm{CAB}$ and OSHRC, already noted, the prolonged history of attempts to reform the NLRB review system is graphic evidence of the futihty of expecting significant progress on an ad hoc basis. In submitting a recent proposal to authorize certiorari review by the NLRB and to increase the finality of the decisions of NLRB administrative law judges, Congressman Thompson pointed out:

The substance of this proposal is not new or novel. It was recommended by the panel of experts chaired by Archibald Cox in 1959; by President Kennedy in his Reorganization Plan of 1961; by the Pucinski subcommittee in 1961; and by this subcommittee in $1968 .^{31}$

Experience thus shows that the federal agencies are unlikely to endorse uniform review standards or to make significant changes in their review processes without prolonged, concerted pressure. Indeed, the definition of permissive review standards recommended by the permanent ACUS since 1968 is weaker than that adopted by the temporary ACUS in the early $1960{ }^{\prime} \mathrm{s}^{32}$

From the point of view of this author, as an administrative law judge, uniform review standards would appear to be fully justified in light of the shortcomings of the administrative process as it has evolved under the APA. At the core of the APA safeguards is the guaranteed independence and merit selection of the administrative law judges who are to conduct hearings under the Act. To ensure their independence, the APA entrusted the Civil Service Commission with the sole responsibility for the certification, classification and pay of the administrative law judges; ${ }^{33}$ and the Act further provided that a judge could be removed only for cause after an APA hearing before the Civil Service Commission. ${ }^{34}$

See Recommendation No. 6, supra note 29; Comment, ABA Proposals for Amendments to Administrative Procedure Act, 24 AD. L. REv. 371, 400-01 (1972). It remains to be seen whether this is a surrender to the Administrative Conference position or a temporary cease-fire.

31. Hearings on H.R. 7152, Before the Special Subcomm. on Labor of the House Comm. on Education and Labor, 92d Cong., 1st Sess. 7-8 (1971).

32. Compare Administrative Conference of United States Recommendation No. 9, supra note 26, with Recommendation No. 6, supra note 29.

33. Administrative Procedure Act $\$ 11,5$ U.S.C. $\$ \S 5362,7521$ (1970).

34. Id. $\$ 7521$. Under the Commission's regulations, the agencies' appointnuents of administrative law judges are unconditional; the names of candidates are referred to the agencies in the order of their score on the register of qualified candidates; and agencies are forbidden to give judges assiguments that might conflict with their duties, responsibilities and independence. In addition, under APA provisions, a judge may withdraw from a case if he deems himself to be disqualified 
At present about 780 federal administrative law judges conduct hearings subject to the due process guarantees of the APA. Because of the safeguards that surround this position, the administrative judiciary provides an independent, impartial forum for the trial of administrative cases pending before federal agencies. However, after the hearing the agencies have virtually unlimited power to change or reverse the decisions of the judges. As stated in section 8(a) of the APA: "On appeal from or review of the imitial decision, the agency has all the powers which it would have in making the imitial decision except as it may limit the issues on notice or by rule."35

In many cases agencies delegate their review authority to subordinates appointed without standards of selection or qualifications, or tenure rights that would protect against agency control or influence. $^{36}$ A substantial question must be raised as to whether the $a b-$ sence of controls over the selection, qualifications and impartiality of such officials has tended to impede the basic fairness, integrity and efficiency of the federal administrative process. The investigation proposed by this article is designed to examine this issue in depth.

An even more crucial problem is the lack of standards governing agency review. The agencies generally recognize no standards of review, save the thin guidelines of Universal Camera Corp. v. $N L R B,{ }^{37}$ and under section 8 of the APA they are not required

to consider a particular matter; ex parte communications within and outside the agency are forbidden; and the agencies are required to assign cases to the judges on a rotational basis to the extent practicable. The processes used in screening applicants for appoinfment to this position under the APA are stringent. Each applicant must undergo a thorough investigation of his character and qualifications and must take written and oral examinations to test his judicial capacity and fitness. In practice, only about oue in ten applicants qualifies for a position on the register and far fewer are selected to fill an administrative judgeship. See, e.g., U.S. Civil Service Commission Announcement No. 318 (rev. Nov. 1972).

35. 5 U.S.C. $\$ 557$ (b) (1970).

36. Of the 23 federal agencies that conduct APA adjudicatory hearings, see note 38 infra, nearly one-half have delegated authority to subordinate officials to decide appeals from the decisions of administrative law judges: Dep't of Agriculture, 7 C.F.R. $\$ 2.35$ (1973); AEC, 10 C.F.R. $\$ 2.785$ (1972); EPA, 40 C.F.R. $\$ 164.2$ (c) (1972); FCC, 47 C.F.R. $\$ 0.161$ (1972); Dep't of Interior, 43 C.F.R. $\S \S 4.1(2)-$ (5), .5 (1972); ICC, 49 U.S.C. $\$ \S 17(2)$-(5) (1970); Postal Service, 39 C.F.R. $\S \S 952.25,953.14,954.20$ (1972); SEC, 17 C.F.R. $\$ 200.30-6$ (1972); Social Security Administration (HEW), 20 C.F.R. $\$ 422.205$ (1972); Dep't of Treasury, 26 C.F.R. $\S 178.77,181.79,200.107$ (1972).

37. 340 U.S. 474 (1951). 
to do more. As shown above, agency review frequently amounts to a de novo appraisal of the administrative hearing, causing substantial delay, expense, and doubt as to the value of the right to such a hearing.

This author believes there is an urgent need to examine-on an APA program-by-program basis-whether public service, justice, and efficiency are achieved when costly hearings records are reviewed de novo despite a decision by an independent adminstrative law judge. However impartial the hearing may be, the safeguards it affords are plainly doubtful if the findings of the presiding judge are entitled to no consistent weight on appeal and are not to be tested by predictable standards. The research proposed here would request eacl agency to identify, for eacl relevant APA program, the benefits it behieves are derived from the power to review administrative judges' decisions without standards of review.

For certaim programs the maintenance of agency policy direction may be contended as a major benefit derived froin unstructured review processes. It is also possible that where review of the decisions of administrative law judges is by the agency itself, the agency will argue that it can more easily bring its developed expertise to bear upon the matter at hand without specific, limited standards of review. Research is needed to test such positions, to see whether the benefits contended are not outweighed by major costs, delays and uncertainty involved in subjecting a trial record to unlimited or standardless review.

If a particular category of APA cases involves the application of clear standards to a complicated set of facts, or if matters of credibility are primarily at issue, thorough research may convince the agency that its decisional process would be significantly improved by standards of review. On the other hand, in certain cases the agency's arguments for plenary review power may show a need for exempting the program from the APA's adjudicatory hearing requirements. Thus, in matters such as complex rate-making proceedings which are likely to have a substantial economic impact upon a particular industry or geographic area, the real justification for the agency's desire to retain plenary review authority may lie in the quasi-legislative clraracter of the proceedings. Research may show that sucl cases should be frankly treated as rule-making and excluded from APA adjudicatory procedures.

Comprehensive research of current practices is likely to unfold 
a spectrum of proceedings ranging from narrow adjudications of factual or credibility issues to areas depending far too much upon policy or discretionary decisions to admit of effective adjudicatory standards. Thus, at one end of such a spectrum it may be appropriate that decisions of administrative law judges be made by law the final decision of the agency, while at the other end it might be appropriate to eliminate the involvement of administrative law judges altogether. One of the purposes of the investigation proposed here is to determine whether any adjudicatory proceedings that warrant an APA judge's decision justify plenary review power in the agency.

It is not the view of this author that arguments against uniform review standards should be summarily rejected. It seems evident, however, that a prima facie case for uniform review standards has been made by past and present leading authorities (including the Hoover Commission and Task Force, the Senate Subcommittee on Administrative Practice and Procedure, and the Ash Council), and that the burden must now shift to the agencies (where applicable) and to the ACUS to explain why they should not be adopted. Such an approach obviously requires a comprehensive, current evaluation of the administrative process as it functions in each agency. The subject is too complicated and unwieldy to permit of effective evaluation without thorough investigation and a disciplined searching for the relevant facts.

The research should also be designed to evaluate the probable advantages and disadvantages of specific proposals for possible revision of the APA. In that way the contentions for and against change can be brought to their sharpest focus. In this connection, it is submitted that the problems of delay, mefficiency and lack of integrity in agency review processes raise four critical issues concerning possible revision of the APA. These are:

1. Is there a need to require selection and qualification standards for agency appointments of review officials, with tenure rights to protect against agency influence?

2. Should agency review of the decisions of administrative law judges be discretionary-that is, a certiorari-type review?

3. Should agency review of the decisions of administrative law judges be limited by uniform standards comparable to those of federal appellate courts?

4. Should the decisions of administrative law judges be made, by law, the final decision of the agency in certain areas-for exain- 
ple, where the statutory standards for administrative sanction or redress have been spelled out in detail?

The resolution of such basic questions will require thorough examination of each agency's review process. The agenda that follows is proposed as the starting point.

Nearly a generation of Americans has coine under the impact of government decision making since outstanding authorities urged major changes in the APA. If these researchers have been right, the costs of mefficiency, waste and the frustration of basic due process rights have already been too high a price to pay. Prompt action is necessary to re-examine our decisional process and, where necessary, to improve it by effective legislation.

\section{AGENDA FOR INVESTIGATION \\ I. APA AGENCIES \\ II. REVIEWS BY APPEALS OFFICIALS APPOINTED BY AGENCY \\ III. REVIEWS BY AGENCY HEADS \\ IV. COMPARATIVE ANALYSIS OF FINDINGS IN PARTS II AND III \\ V. APA CASES ANALYZED BY SUBJECT MATTER- SHOULD THE APA JUDGE'S DECISION BE FINAL IN CERTAIN AREAS? \\ VI. CONCLUSIONS AND RECOMMENDATIONS}

\section{APA AGENCIES}

List the federal executive and independent agencies that employ (APA) administrative law judges-that is, agencies which conduct adjudicatory hearings subject to APA. ${ }^{38}$

38. At the time of this writing there are 23 federal agencies that conduct APA adjudicatory hearings: Dep't of Agriculture, 7 C.F.R. \$ 2.41 (1972); AEC, 10 C.F.R. § 2.704 (1972); CAB, 14 C.F.R. \$\$ 302.22, 26 (1972); Civil Service Comm'n, 5 C.F.R. $\$ \S 151.133,151.135,831.1106,930.226$ (1972); Coast Guard, 46 C.F.R. $\$ 137.20$ (1972); EPA, 40 C.F.R. $\$ 1164.20, .26, .28$ (1972); FCC, 47 C.F.R. § 0.151 (1972); FDA (HEW), 21 C.F.R. $\$ 2.71$ (1972); FPC, 18 C.F.R. $\S \S 1.20,27$ (1972); FTC, 16 C.F.R. $\$ 3.42$ (1972); Dep't of Interior, 43 C.F.R. $\S 4.1$ (1972); ICC, 49 C.F.R. $\S \S 1100.5(\mathrm{f})$, (g), .70 (1972); Dep't of Labor, 29 C.F.R. $\$ \S 5.11,6.10,31.11,40.20$ (1972); Maritime Administration, 46 C.F.R. \$201.19 (1972); Maritime Comm'n, 46 C.F.R. \$ 502.142 (1972); NLRB, 29 C.F.R. $\S \S 203.15,204.62, .72$ (1972); Nat'l Transp. Safety Bd., 14 C.F.R. § 421.29 (1972); Occupational Safety \& Health Review Comm'n, 29 C.F.R. $\$ 2200.21$ (1972); Postal Rate Comm'n, 39 C.F.R. $\$ \S 3001.5(j)$, .30 (1972); Postal Service, 39 C.F.R. $\$ \S$ 952.17, 953.11, 954.14 (1972); SEC, 17 C.F.R. \& 201.11 (1972); Social Security Administration (HEW), 20 C.F.R. $\$ 422.203$ (1972); Dep't of Treasury, 26 C.F.R. $\S \S 178.76,181.73,181.75,200.97$ (1972), 31 C.F.R. $\$ 10.65$ (1972). 


\section{REVIEWS BY APPEALS OFFICIALS APPOINTED BY AGENCY ${ }^{39}$}

A. Identification of agencies which employ appeals officials (review boards, appeals council, judicial officers, etc.) to decide appeals from decisions of APA judges (for each agency, conduct the following studies-B through I).

B. Summary of appeals procedures and standards of review (for each class of APA adjudicatory cases decided by an agency, summarize the following)

1. How are appeals taken? Is there an automatic right of appeal to the agency review authority, or is review by certiorari? Are interlocutory appeals permitted?

2. Does the agency retain the right to review on its own motion?

3. If review is by certiorari, what standards determine the grant or denial of review?

4. Does the agency apply any recognized standards of reviewfor example, the "clearly erroneous" doctrine, the "substantial evidence" rule, or the doctrine of "clear abuse of discretion"?

Summarize any standards of review spelled out by regulation or published rules.

C. Appoimtment and qualifications of appeals officials

1. How does the agency select its appeals officials? Is selection competitive or non-competitive? Is it subject to Civil Service standards? What criteria, if any, are used to determme judicial capacity, objectivity, character and professional experience and qualifications? Is a law degree required? Is admission to the bar required?

2. What are the pay, classification, job description, promotion and tenure rights (to resist discharge, layoff, transfer and deinotion) of appeals officials?
a. Are appeals officials subject to
1. Quality pay increases?
2. Denial of step increases in pay?
3. Paid sabbaticals?
4. Performance ratimgs?

3. Are any patterns evident with respect to
a. Pohtical tests for appointment?
b. Turn-over of appeals officials after change in administra- tion?
c. Dismissal or transfer actions agaimst appeals officials related to nature of their decisions?
d. Possible conflicts of interests based upon appeals officials' employment before appoimtment and their eniployment after leaving the agency?

D. Authority of appeals officials

1. Summarize the types of cases heard by appeals officials.
a. What types are APA cases?
b. What types are non-APA cases? ${ }^{40}$

39. The scope of personnel intended by this term is defined in note 3 supra. See also note 42 infra.

40. With the exception of this item, all studies and research should be confined to APA adjudicatory proceedings. 
c. Roughly, what percentage of appeals cases are APA cases?

2. Does the agency delegate final authority to the appeals official(s), or does it reserve the right to review his decision, take a case from him, or bypass him? What procedures and standards apply to agency reviews of the decisions of its appeals official(s)?

3. How are cases assigned to an appeals official? Is assignment automatic? If there is more than one appeals official, are cases rotated to appeals officials or does the agency exercise the right of selection im assignimg individual appeals? For example, does a chairman of a board of appeals maintain the right to select a panel to hear a given appeal?

4. Does the agency retain the power to appoint ad hoc panels or members of an appeals body, or to appoint ex officio members of appeals bodies? If so, develop the items in part II.C, above, with respect to the appointment and qualifications of ad hoc and ex officio appeals officials.

E. Statistics of appeals officials' decisions

1. What percentage of their decisions are favorable to the agency? ${ }^{41}$

2. What percentage are adverse to the agency?

3. What percentage of appeals are reinanded for further administrative hearing?

4. What percentage reverse

a. Administrative hearings decisions?

b. Administrative hearings decisions that are favorable to the agency?

c. Administrative hearings decisions that are adverse to the agency?

5. What percentage of appeals decisions are further reviewed by the agency?

6. What is the average time spent im agency review-that is, how long after the APA judge's decision is the agency's final decision reached?

7. On appeal to the courts

a. What percentage of appeals officials' decisions are upheld by the courts?

b. What percentage are reversed by the courts?

c. What percentage are remanded for further proceedings before the agency?

F. APA judges' decisions (for each class of APA adjudicatory cases, summarize the following)

1. Is the APA judge's decision usually an initial decision or a recommended decision?

2. What percentage of judges' decisions are favorable to the agency?

3. What percentage are adverse to the agency?

41. Statistics on "favorable" and "adverse" decisions should be confined to adversary cases in which the agency or an arm of the agency is a party. 
4. What percentage of judges' decisions become the final decision of the agency without review within the agencywhere no appeal is taken by a party or initiated by appeals authority on its own motion?

5. What types of cases, if any, have been delegated to the APA judges for final agency decision with no right of appeal in the agency?

a. As to any such cases, summarize substantive program, sanctions or relief authorized by statute or regulation, and court procedures available after the administrative law judge's decision.

G. Evaluation of decisions of appeals officials (for each main class of APA adjudicatory cases, evaluate a substantial and representative sample of decisions of appeals officials in terms of judicial quality -imcluding professionalisin, consistent and logical reasoning, objectivity, and fundamental fairness-compared to the given APA judge's decision being reviewed).

1. Do the appeals decisions tend to give appeal consideration to the $A \overline{P A}$ judge's decision, or are they more inclined to take a de novo approach to the evidence and the issues?

a. Is there a difference on this score when the lower decision is a "recommended decision" as opposed to an "initial decision" of the APA judge?

2. Do the appeals decisions apply any standards of review in determining the weight to be given to

a. Findings of fact?

b. Discretionary rulings by the APA judge?

3. How does the agency construe, and apply, the doctrine of Universal Camera Corp. v. NLRB, 340 U.S. 474 (1951), in considering the weight to be given to administrative findings of fact?

4. How does the appeals authority handle precedents-prior agency decisions?

5. Do the appeals decisions bascially reflect an objective consideration of the issues and the evidence, or do they tend to indicate an agency bias?

6. How do the appeals officials' analysis and reasoning of the issues coinpare with courts of appeals' decisions? Is the "brand of justice" comparable? Does the use of dicta tend to be greater or less than that of the courts?

7. What functions are actually being performed by the appeals officials as reflected by the net results of their decisions?

8. Could the functions identified in item 7, above, be as effectively performed if

a. The appeals officials were independent of the agency with respect to tenure rights (had the same independence as APA judges)?

b. The appeals officials were required to apply standards of review that prevented thein from

1. Setting aside a finding of fact unless shown to be clearly erroneous?

2. Setting aside a finding of fact unless the record showed 
no substantial evidence supporting it?

3. Setting aside a discretionary ruling by the APA judge unless the record showed a clear abuse of discretion?

9. Where applicable, what happened to the case in the courts? Summarize court's reasoning.

H. Evaluation of possible changes

The research of the agency's review processes should include a careful comparative evaluation of positive and negative values that might derive from certiorari review by the agency, judicialized agency review standards, and standards for the selection and impartiality of review officials appointed by the agency. For example, positive values might include: increased respect for law and government, stability of admmistrative adjudications, reduction of delays and expense, reduction of political influence upon agency decisions, and increase in efficiency by more precise definitions of agency objectives and guidelines; and negative values might be: impairment of flexibility of decisional process, hampering exercise of delicate pohicy-making authority, and possible increase in delays and expense by inviting technical and legalistic issues, im short, "over-judicializing" the administrative process.

The study should also include a careful analysis of the distinctions (real and apparent) between agencies' adjudicatory and quasi-legislative (rulemaking) proceedings and the different due process considerations involved. Perhaps changes should require agencies to distinguish between these categories and apply judicialized review standards for proceedings that are truly adjudicatory or for issues that are truly adjudicatory.

Conclusions reached by overall evaluations should be apphed individually to each agency system and its individual APA adjudicatory programs.

I. Other

Identify other factors that might further the research to determine whether a lack of restrictions on agency appellate appointment and review authority tends to work imjustice on the parties or to impede efficient governmental processes.

1. This might include a comparative analysis of courts of appeals statistics-what percentage of U.S. district court decisions (in cases comparable to admmistrative hearimgs under the APA) are reversed by the courts of appeals? Affirmed? Remanded? How does the court of appeals system coinpare with the agency review systein(s) in overall quality and efficiency?

2. Research should include the courts' evaluation of possible revisions of the APA. In what way would the courts' review of agency decisions be affected by requiring the agencies to judicialize their review of APA judges decisions? Opinions should be sought from individual judges as well as from the Judicial Conference.

3. Additional study inay include a comparative analysis of other administrative law systems-for example, the French Conseil d'Etat, which functions as a supreme administrative court, 
and the British system.

4. Additional research may include opinion polls of the reactions of litigants, bar groups, government officials, attorneys, industry and labor organizations, law schools, universities, other groups, etc., as to the fairness and efficiency of the existing agency review systems and the need for change, if any.

\section{REVIEWS BY AGENCY HEADS}

For each agency histed in Part I, conduct the following studies of reviews by head of the agency (single or inultiple "agency" as defined in APA). ${ }^{42}$ Findings from the studies in Part II should be incorporated to avoid duplication where possible.
A. Summary of Appeals Procedures and Standards of Review
Summarize same iteins as those specified in Part II.B (1-4).
B. Statistics of Agency Review Decisions
Tabulate same type statistics for agency heads' decisions as those specified for appeals officials in Part II.E.
C. APA Judges' Decisions
Tabulate same data as those specified in Part II.F in cases in which APA judges' decisions are reviewed by agency heads.
D. Evaluation of Agency Review Decisions
Evaluate a substantial and representative sample of decisions of agency heads for the same factors as those specified in Part II.G.
E. Conduct same evaluations for agency-head review systems as those indicated under Part II.H.
F. Other
Conduct further investigation as indicated in Part. II.I.

\section{COMPARATIVE ANALYSIS OF FINDINGS IN PARTS II AND III}

A. Do the statistics found in II.E differ significantly from those found in III.B? What inferences inay be drawn?

B. Do the statistics found in II.F differ significantly from those found in III.C? What inferences may be drawn?

C. Do the evaluations of decisions under II.G differ significantly frow those reached under III.D? What inferences inay be drawn?

D. Are there significant differences between the evaluations reached under II.H and III.E? What inferences may be drawn?

V. APA CASES ANALYZED BY SUBJECT MATTER-SHOULD THE APA JUDGE'S DECISION BE FINAL IN CERTAIN AREAS?

42. 5 U.S.C. $\$ 551$ (1970). In addition, for the convenience of research classification, review by any Senate-confirmed appointee should be reported and evaluated under Part III even though the appointee is not an agency head or member under the APA. 
Using the findings from Parts II, III and IV as the starting point, evaluate each agency's categories of APA adjudicatory cases to determine whether in certain cases the APA judge's decision should be made, by law, the final agency decision. For example, are there classes of cases in which the statutory standards for administrative adjudication are so clear, or by amendinent could be made so clear, that the congressional purpose would best be served by eliminating the expense and delay of agency reviews of APA judges' decisions? Such cases would still be reviewable in the courts, to the extent that judicial review is available under the existing statute or under the APA.

\section{CONCLUSIONS AND RECOMMENDATIONS}

When the above research is completed in an agency, summarize the evaluations and conclusions reached as to the agency's review system(s); and resolve the following basic questions with recommendations.

A. Should the appoimtınent of agency review officials be brought under selection and qualification standards, with tenure rights to protect against agency influence?

\section{Recommendations:}

1. If this issue is answered in the affirmative, draft annendment(s) to the APA that would accomphish the change(s) recommended. State reasons for recommendations.

2. If the issue is answered in the negative, state reasons for answer and indicate whether any change in the appointment system is recommended.

3. State any other recommendations found to be appropriate to this issue.

B. Should agency review of the decisions of adininistrative law judges be discretionary-that is, a certiorari-type review?

This issue should be answered separately as to

1. Reviews by appeals officials appointed by agency.

2. Reviews by head of agency.

\section{Recommendations:}

1. If either issue is answered in the affirmative, draft amendment(s) to the APA that would accomphish the change(s) recommended. State reasons for recommendations.

2. If either issue is answered in the negative, state reasons for answer.

3. State any other recommendations found to be appropriate to these issues.

C. Should the scope of agency review of the decisions of APA judges be limited by uniform standards comparable to those of federal appellate courts?

This issue should be answered separately as to

1. Reviews by appeals officials appointed by agency.

2. Reviews by head of agency. 


\section{Recommendations:}

1. If either issue is answered in the affirmative, draft amendment(s) to the APA that would accoinplish the change(s) recommended. State reasons for recommendations.

2. If either issue is answered in the negative, state reasons for answer and indicate whether any change in the review systein is recommended.

3. State any other recommendations found to be appropriate to these issues.

D. Should the decision of the APA judge be made, by law, the final decision of the agency in certain areas?

\section{Recommendations:}

1. If this issue is answered in the affirmative, identify each category of APA cases for which finality of APA judge's decision is recommended and as to each such category

a. State detailed reasons for the recommendation.

b. Draft amendment(s) to substantive statute(s) and the APA that would accomplish finality of judge's decision.

2. State any other recommendations found to be appropriate to this issue.

E. Other conclusions and recommendations

Do the investigative findings indicate other changes that would improve the basic fairness or efficiency of the federal administrative process? For example, does the investigation imdicate that certain APA proceedings should be excluded from the adjudicatory hearing requirements of the APA because the decisional authority of the agency rests too inuch upon discretion to admit of effective adjudicatory standards? 

. 